\title{
Philo of Alexandria's Use of Sleep and Dreaming as Epistemological Metaphors in Relation to Joseph
}

\author{
M. Jason Reddoch \\ Assistant Professor, Department of Language and Literature, \\ Colorado Mesa University, Colorado \\ jreddoch@coloradomesa.edu
}

\begin{abstract}
Dreams are used figuratively throughout Greek literature to refer to something fleeting and/or unreal. In Plato, this metaphorical language is specifically used to describe an epistemological distinction: the one who has false knowledge or opinion is said to be dreaming while the one who has true knowledge is said to be awake. These figures are also central to Philo of Alexandria's philosophical language in De somniis 1-2 and De Iosepho. Although scholars have documented these epistemological metaphors in Plato and related treatments of the concept of sleep in Heraclitus, it has not been discussed in any detail in relation to Philo's treatment of Joseph in these two treatises. In De somniis 1-2, Philo primarily emphasizes his role as a dreamer and thus one incapable of true knowledge. In De Iosepho, Joseph is a dream interpreter who is not only awake but also capable of interpreting the figurative dream of life to which most people are subject. Although some scholars have considered these treatises contradictory in terms of their treatments of Joseph, an analysis of Philo's figurative use of sleep and dreaming reveals that they are a part of a coherent exegetical framework.
\end{abstract}

\section{Keywords}

Philo of Alexandria, dreams, sleep, Plato, Heraclitus, metaphor, epistemology

\section{Introduction}

Different kinds of metaphors and similes related to the idea of a dream occur broadly throughout Greek literature, but most often a dream is used 
figuratively to refer to something unreal and/or fleeting. ${ }^{1}$ Plato is the first to apply this understanding of a dream to the state of dreaming in order to speak figuratively about epistemological clarity. ${ }^{2}$ One who mistakes something unreal or fleeting for something real and permanent does not have true knowledge and thus may be described as experiencing a dream. Although Heraclitus never refers to dreams per se in the extant fragments, he uses the concept of sleep in epistemological contexts and in this way may be said to have prefigured Plato. ${ }^{3}$ It is not uncommon to find isolated examples of sleep or dreaming to describe a bad idea or a form of ignorance; however, the extensive use of it to make a serious point about true and false knowledge is rare. ${ }^{4}$ This figurative language has been discussed in some detail by scholars in relation to Heraclitus and Plato; however, it has not been documented in any detail in relation to Philo of Alexandria who uses it extensively in De somniis 1-2 and De Iosepho. ${ }^{5}$

1) Esp. of öv $\alpha \rho$ (LSJ s.v. I.2) and őveıpo (LSJ s.v. I.3). See A.H.M. Kessels (1978) 226-54 for a survey of the use of dreams in similes and metaphors in Greek literature. Also see W.V. Harris (2009) 139-141, who argues that the use of dreams to describe something insubstantial is evidence of widespread skepticism.

2) Plato often refers literally to prophetic dreams in a positive way, but rarely uses dreams figuratively to refer to something positive. See Resp. 4.443b7-c2, where a fulfilled dream is used to refer to a point in the discussion that should be accepted as valid. On this passage, see H.D. Rankin (1964) 75-83.

3) See esp. DK 22 fr. B 1, 21, 26, 73; on these fragments, see R.G.A. Lieshout (1980) 67-85, J. Mansfeld (1967) 1-29, R. Polito (2003) 53-70, and C. Brown (1986) 243-45. Also see H. Granger (2000) 260-81, who discusses Heraclitus' use of sleep in order to explain how Heraclitus portrays the masses of foolish people like the dead in a similar manner as Homer.

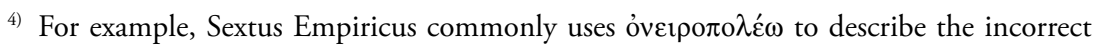
dogmas of other philosophers: $P H 1.91 .3 ; 2.157 .1 ; 3.41 .6 ; 3.156 .2 ; 3.240 .3 ; 3.273 .2$; and Adv. Math. 7.245.5; 8.57.8-9. In Philodemus' De pietate (Col. 1, line 1450), dreaming is used in the form of a simile to refer to those who are mentally imbalanced; see D. Obbink (1996) 522 for further references related to this passage. Also see Cicero, Nat.D. 1.42 where the somnia delirantium are contrasted with the iudicia philosophorum.

5) According to V. Mikeš (2007) 229-49, Heraclitus is the first to use sleep to refer to an inferior cognitive state, and Plato then applies this to the dream. On pp. 247-8, Mikes briefly mentions Philo's use of this language in Ios. 125-45 and suggests that it contains elements of Heraclitus and Plato. See p. 249 for an English summary of the article.

On Plato's use of dreams as similes or metaphors, see A.H.M. Kessels (1978) 236-42; D. Gallop (1971) 187-201; S.S. Tigner (1970) 204-12; P. Louis (1945) 139, 197. 
These treatises have received considerable scholarly attention because they appear to provide contradictory interpretations of Joseph. In De somniis 2, Joseph is presented negatively as one who is subject to a broad array

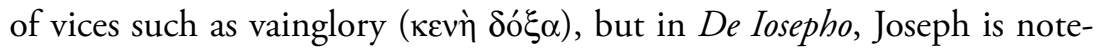
worthy primarily for his virtue as a leader. ${ }^{6}$ It has been suggested that Philo's inconsistent attitudes reflect either his inability to manage his sources well or a shift in the political climate in Alexandria. ${ }^{7}$ Others have argued that the difference is best explained by Philo's audiences. Whereas De somniis 2, along with the rest of the allegorical commentary, was intended for a Jewish audience, De Iosepho was aimed at a gentile readership. ${ }^{8}$ Often closely related to this notion is the idea that in De somniis 2, Joseph is actually a veiled symbol for the corrupt Roman leadership in Alexandria. ${ }^{9}$ All of these approaches are similar in that they view the differences between the two treatises as actual contradictions of substance, which need to be reconciled. In contrast, more recent scholarship has emphasized that Philo's portrayal of Joseph is not as conflicted as previously thought. This is based on the idea that Philo saw Joseph as a multi-faceted character and could thus be seen from different perspectives. In this way, the differences are a matter of focus and Philo's exegetical intentions in a given passage or text. ${ }^{10}$

In this article, I will provide an analysis of Philo's treatment of Joseph that does not assume a contradiction and is thus in line with the second

6) For surveys of scholarship on these two texts, see E. Hilgert (1986) 262-70 and (1987) 394-402.

7) See V. Nikiprowetzky (1977) 170-4 and 192-3 for a discussion of scholarship on these points respectively.

8) E.R. Goodenough (1938) 42-63.

9) E.R. Goodenough (1938) 21-41; J. Laporte (1964), 16-8; S. Sandmel (1979) 103-4; For criticism of this idea specifically, see V. Nikiprowetzky (1977) 217-9, n. 161.

10) See F.H. Colson (1935) xii-xv, who emphasizes that the apparent contradiction is part and parcel of Philo's exegetical approach. According to V. Nikiprowetzky (1977) 217-9, n. 161, the apparent contradiction is a product of Philo's thinking that the politician himself contains conflicting qualities. According to J.M. Bassler (1985) 240-55, there are different exegetical foci. He says that De somniis 2 is really about the soul while De Iosepho is really about the statesman, and in the end the differences can be accounted for in terms of three dichotomies which juxtapose contrasting elements between De Iosepho and De somniis 2: Joseph's whole life story/an episode in his life; the politician/the soul; narrative along with allegory/strict allegory. Also see M. Petit (1987) 41-53 and F. Frazier (2002) 1-30. 
school of thought. I will show that Philo's treatments of Joseph may be different but are not contradictions of substance when viewed in terms of Philo's use of epistemological metaphors based on the concepts of sleep and dreaming. The evidence suggests that the basic metaphor is Platonic in origin but that Philo or his source innovated by expanding it to include the dream interpreter as well. Whereas the dreamer is one who is subject to an epistemological limitation and thus asleep to the truth, the dream interpreter is the one who has knowledge and is thus capable of dispelling ignorance. Philo uses these metaphors to interpret Scripture, and thus the portrayal of Joseph in De somniis 2 is primarily negative since Philo focuses on him as a sleeper and a dreamer; in De Iosepho, Philo emphasizes Joseph's role as a dream interpreter and thus presents him more positively. The two presentations of Joseph are not conflicting since Philo thought that Joseph underwent a transformation between his dream experiences as a young man and his later role as a dream interpreter.

\section{The Figurative Language of Sleep and Dreaming in De somniis 1-2}

It is possible that Philo was influenced by biblical literature in his use of this figurative language, but there is very little evidence for it. ${ }^{11}$ The only other author prior to Philo to use it extensively to make epistemological claims is Plato. In general, Plato may describe an instance in which one has a mistaken or uncertain form of knowledge as a dream or a state of dreaming. ${ }^{12}$ The lives of most people may be characterized as a dream in which reality is not truly apprehended. ${ }^{13}$ In terms of specific idiomatic

11) The concept of dreaming is not used figuratively in the Pentateuch, which Philo primarily cites; however, it does appear in limited fashion in other biblical literature. The only passage where there is an epistemological connotation is in Isaiah 29.7-8, but there is no clear influence of this passage on Philo. See Laberge (1978) 25-8 for a comparison of the Hebrew and Greek of this passage; cf. Zeitlin (1975-6) 8-10. Also see Job 20.8 and Psalms 72.20 where dreams are used in a comparison to emphasize impermanence and/or insubstantiality; cf. Ecclesiastes 5.1-6 and Wisdom of Ben Sira 34.1-7.

12) E.g. Meno 85c and Symp. 175e, where uncertain knowledge is compared to a dream in a simile using övop. Also see $L y .218 \mathrm{c}$ and Tht. 208b where a piece of false or deceptive

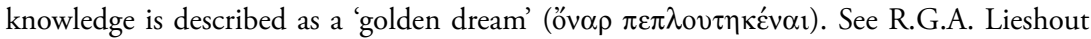
(1980) 116 on the golden dream in Plato.

13) At Ap. 31a, Socrates explains that most people spend their lives in a figurative sleep from which he is divinely ordained to wake them. Cf. Resp. $7.520 \mathrm{~b}-\mathrm{c}$, where the ideal city is said 
constructions, Plato is fond of using $\ddot{\pi} \pi \alpha \rho$ and öv $\alpha \rho$ to distinguish between true and false perception. The one who has knowledge of the Forms is awake, but the one who has knowledge only of particulars is in a dream. ${ }^{14}$ Similarly, figurative dream knowledge is specifically associated with Plato's

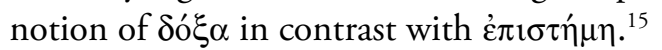

Philo does not use the same idiomatic constructions, but his use of the metaphor is conceptually quite similar. The main difference is due to the exegetical nature of Philo's treatises. Plato invokes the figurative language of sleep and dreaming when he wants to make a point that actually has nothing to do with sleep and dreaming in a literal sense. In other words, they are just figurative ways of describing something fleeting or a person who lacks knowledge but are not the actual topic. Philo also does this, but in De somniis 1-2, the primary objects of exegesis are dreams and people who are in a state of dreaming. As a result, references to sleep and dreaming in the text become points of departure to discuss lack of knowledge. This is what distinguishes Philo as a philosopher whose primary medium of discourse is allegorical exegesis. Instead of simply drawing on imagery to explain his philosophical ideas, his philosophy also emerges from the imagery in the biblical narrative. In this way, Philo not only invokes sleep and dreaming to explain knowledge but also invokes knowledge to explain references to sleep and dreaming in the text.

A clear example of how Philo interprets the biblical text in terms of this figurative language is when he is interpreting the Chief Butler's description of his dream (Gen. 40.9-11). ${ }^{16}$ Before focusing on the dream itself, which is primarily interpreted as an allegory of drunkenness, Philo points out that the Chief Butler began his description of his dream by saying in my

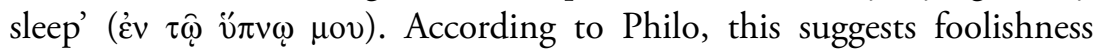

to be ruled by those who are, as it were, awake. In contrast, most cities are ruled by leaders in a dim sleep.

14) At Resp. 5.476c-d, Socrates asks whether the one who believes in beautiful things but not beauty itself lives his life in a dream or awake (óv $\alpha \rho$ ì ü $\pi \alpha \rho)$ ) cf. E.A. Havelock (1963) 190 and B. Näf (2004) 59, both of whom briefly mention this passage in relation to the importance of Plato's metaphorical dream language. See P. Louis (1945) 197 for a full list of passages where $0 ँ \pi \alpha \rho$ and öv $\alpha \rho$ are contrasted. For further discussion of this construction, see A.H.M. Kessels (1978) 239-41. This phrase also appears in Diogenes Laertius 10.135 (Life of Epicurus) but is not used to make an epistemological point.

15) Plt. 278d-e; Meno 85c; Resp. 7.534c4-d1; on the latter, cf. Clement of Alexandria, Paedagogus 2.10.106.

16) Somn. 2.159-163. 


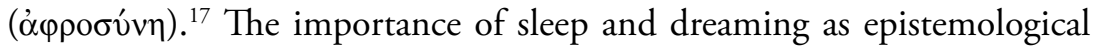
figures becomes more explicit as he goes on to apply his analysis of the

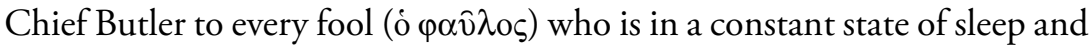
thus barraged by false images:

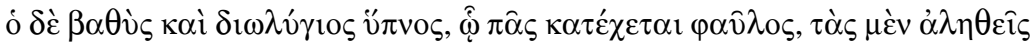

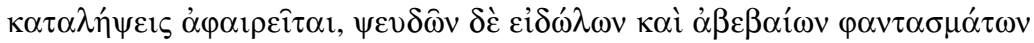

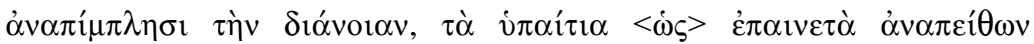
$\dot{\alpha} \pi \mathrm{o} \delta \dot{\chi} \chi \varepsilon \sigma \theta \alpha \mathrm{l}$. (Somn.2.162)

And deep and immense sleep, by which every fool is possessed, destroys true perceptions and fills the mind with false images and unsteady phantoms, persuading [the fool] to accept blameworthy things as praiseworthy. ${ }^{18}$

One can be sure that Philo is not here referring to dreams in a literal sense because at the beginning of the treatise he explicitly classifies the Chief Butler's dream in his third category of predictive dreams sent from God. ${ }^{19}$ The dreamer's tendency to mistakenly perceive something bad for something good (i.e. $\tau \grave{\alpha} \dot{v} \pi \alpha i \tau \imath \alpha / \dot{\varepsilon} \pi \alpha \imath v \varepsilon \tau \alpha$ ) is an idea that recurs throughout $D e$ somniis 1-2 in relation to this figurative language. It is also Philo's way of connecting virtue and knowledge. The one who is figuratively asleep with respect to knowledge is more likely to lack moral uprightness since he is unable to distinguish the good from the bad and thus make correct ethical decisions.

Another example of the connection between virtue and knowledge in the context of this figurative language is a passage where Philo is discussing Jacob's journey from the Well of the Oath to Haran in De somniis 1. On his journey, Jacob sleeps on a rock (Gen. 28.11), and Philo praises his austerity and contrasts him with others who live luxurious lives. Then, describing Moses' presentation of this episode, he explains that the life of those who live more extravagantly is like a sleep and a dream:

\footnotetext{
17) See S. Torallas Tovar (2003) 44, who says that Philo's negative view of sleep is directly connected to folly and drunkenness. She cites Ebr. 204, Sobr. 5, and Migr. 222. According to R.G.A. Lieshout (1980), 77, 85, there is a close connection between sleep and drunkenness in terms of Heraclitus' characterization of sleep as a particularly moist state in which the fiery element is at a minimum.

18) All translations are my own.

19) Somn. 2.1, 5-6.
} 


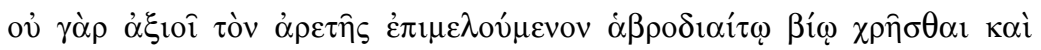

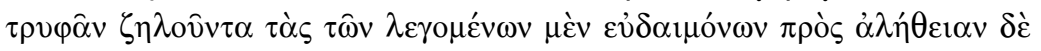

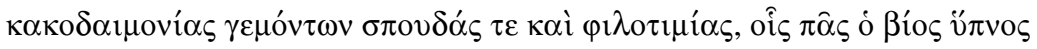

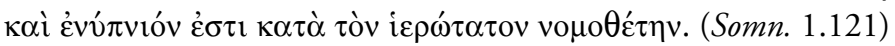

For he (i.e. Moses) does not think that the practitioner of virtue (i.e. Jacob) is worthy to make use of a luxurious life and fare sumptuously while seeking the eagerness and love of honor which belong to those who are said to be happy but in truth are full of misery, for whom, according to the most holy lawgiver, all of life is a sleep and a dream.

Just as the fool confuses the blameworthy with the praiseworthy in the dream of the Chief Butler, here sleepers and dreamers erroneously seek honor and luxury. The point is that those whose lives are full of excess are subject to an epistemological limitation, which causes them to mistake fleeting luxuries and honors for things that are real and permanent. In other words, lack of virtue is the product of a delusion that impedes knowledge.

This connection between knowledge and virtue expressed in terms of the figurative language of sleep and dreaming is central to Philo's negative treatment of Joseph in De somniis 2. At the beginning of this treatise (Somn. 2.8-16), Philo provides some background information on Joseph before going on to interpret the various dream passages. In contrast to the patriarch Isaac with whom Philo associates the Stoic notion that virtue alone is good, he associates Joseph with the Peripatetic idea of the mixed good. ${ }^{20}$ In addition to virtue, the mixed good includes physical and external goods. ${ }^{21}$ In other words, Joseph's tendency to seek material goods beyond virtue alone is the product of his association with the wrong philosophical doctrine. His lack of knowledge leads to a lack of virtue. ${ }^{22}$ These

20) The Stoic position that virtue is the only good is expressed in the phrase $\mu$ óvov $\tau$ ò $\kappa \alpha \lambda$ òv $\dot{\alpha} \gamma \alpha \theta$ òv which also occurs in Philo at Det. 9 and Post. 133 (= SVF III, fr. 31); regarding this concept in the Stoic corpus, see SVF I, fr. 187 and III, fr. 29-67. Also see D. Winston (1984) 412, n. 132 for additional citations and discussion of this concept outside of the Philonic corpus.

21) Other passages in which Joseph is associated with the Peripatetic idea of the three-fold good include the following: Det. 7; Sobr. 13; Migr. 22, 203. Also see SVF III, fr. 136 and Aristotle, EN 1098b (I.viii.2) on the Stoic and Peripatetic positions.

22) Also see Somn. 2.20 on the idea that the one who has clearer dreams is associated with Stoic notion of the good. 
prefatory remarks provide an appropriate introduction to Philo's negative portrayal of Joseph throughout De Somniis 2 since his dreams are allegorically interpreted as the aspiration for fleeting luxury and power.

In both of Joseph's dreams, he symbolically imagines that his family will be subject to him at a future time in Egypt when he becomes a powerful leader there (Gen. 37.7-11). ${ }^{23}$ Philo understands that these are prophetic dreams about Joseph's future and puts them in his second category of dreams sent from God; however, his allegorical treatment of the episodes depends to a large extent on the figurative associations of sleep and dreaming. Joseph's dreams are for Philo an opportunity to discuss the lack of knowledge associated with one who seeks wealth and glory. ${ }^{24}$ In other words, prophetic dreams about future glory are metaphors for the delusions entertained by one who lacks true knowledge and thus seeks material goods. He discusses all kinds of moral weaknesses, but most importantly, he consistently associates Joseph as a dreamer in a deep sleep with the con-

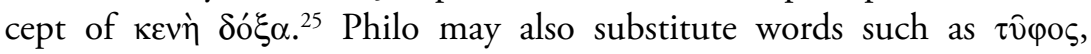

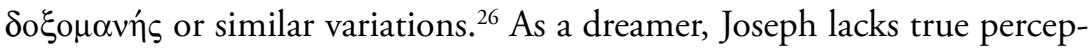
tion and as a result, mistakes fleeting power and possessions for something real and permanent.

Philo's interpretation of Joseph's dreams in terms of the figurative language of sleep and dreaming is made explicit in a difficult passage referring to Joseph's second dream. According to the biblical text, when Joseph describes his second dream, his father responds indignantly. In discussing this passage, Philo posits a hypothetical discussion between Jacob and his son: Joseph defends himself for having the dream on the grounds that the dream simply came to him from some external source without his consent,

\footnotetext{
23) See esp. Somn. 2.17-154 for Philo's exegesis of these passages.

24) See esp. Somn. 2.97, 104-8.

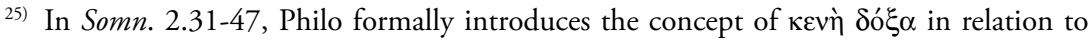

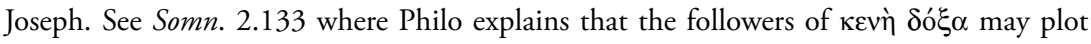
against the practitioners of virtue and bring them to a state of epistemological uncertainty

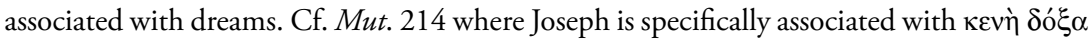

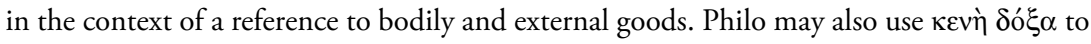
characterize Laban (Fug. 47) and Benjamin (Mut. 96).

26) See T.H. Billings (1919) 72-5, who discusses the close relationship of a number of con-

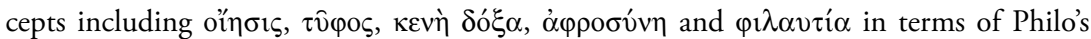
Platonic inheritance. See p. 73, n. 10 for relevant Philonic references. Also see P. Graffigna (1988) on Philo's use of $\tau \hat{\varphi} \varphi \varsigma_{\text {s. }}$
} 
and thus he bears no responsibility for the implication that his family will one day be subservient to him. Amidst this hypothetical conversation, Philo suddenly interrupts to proclaim that the present discussion is not what it appears to be:

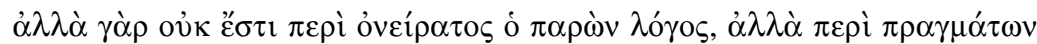

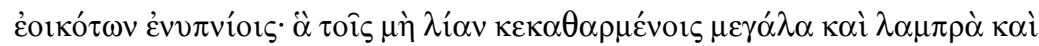

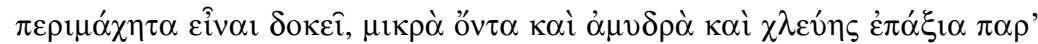

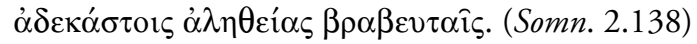

But the present discussion is not about a dream, but about things which seem like dreams; things which seem great and brilliant and worth fighting for to those who are not very pure are actually small, faint, and worthy of mockery among those who are impartial judges of truth.

It has been thought that the distinction being made here between an

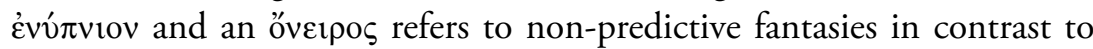
predictive dreams, thus implying that Philo does not consider Joseph's dream predictive. This is based on a terminological distinction used by Artemidorus and incorrectly applied by scholars to Philo, who actually makes it clear at the beginning of De somniis 2 that he considers all the dreams discussed in this treatise predictive. ${ }^{27} \mathrm{~A}$ better explanation is to consider that the distinction Philo is making is between the literal and allegorical meanings of the text. On the one hand, read literally, Joseph had a predictive dream, which suggests that he will one day be rich and powerful. Allegorically interpreted in terms of the figurative language of sleep and dreaming, the dreams and their narrative context are about the desire for fleeting wealth and power experienced by those who do not have

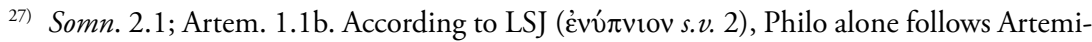
dorus in this distinction. See S. Torallas Tovar (1995) 153-4, where the technical distinction described by LSJ is taken for granted and misapplied to Philo in selective passages. In the proem of book 4 of his Onirocritica, Artemidorus also claims that the words are interchangeable when not being used in the technical sense, and this seems to be the way Philo uses the terms throughout. After all, Philo sometimes collectively refers to all the dreams

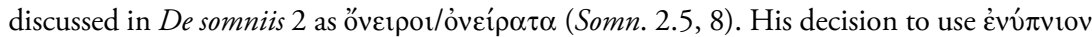
in a given passage seems to some extent to be tied to his citation of it in various biblical passages in which it is used to refer to Joseph's dreams $(2.96,111,135,136)$. On the flexibility of Philo's onirocritical vocabulary, see M. Petit (1974) 152-4. Also see A.H.M. Kessels (1978) 190-2. 
true knowledge. The point of the statement is to show the absurdity of the hypothetical conversation. It treated the narrative as if it were really about a dream when in fact the deeper meaning of the text is not about dreams at all. ${ }^{28}$ It is about lack of knowledge and virtue.

The second part of the passage is similar to the passages above (Somn. 2.162, Somn. 1.121) in which Philo says that the dreamer is unable to distinguish between two categories, one good and one bad. Here Philo describes an inability to understand that things great, brilliant, and worth fighting for are actually small, faint, and worthy of mockery. The point is that the figurative dreamer entertains aspirations that are not at all valued by those who have true knowledge. This method of interpretation based on the figurative associations of sleep and dreaming are the central feature of Philo's negative treatment of Joseph throughout De somniis 2.

\section{Joseph the Dream Interpreter}

Since the negative portrayal of Joseph in De somniis 2 depends to a great extent on the idea of dreaming as a metaphor for lack of knowledge and virtue, it is in this context that any contradictions it may have with $D e$ Iospeho should be considered. De Iosepho is a biographical treatise, which has been interpreted as an attempt to present Joseph as an ideal leader, in a manner consistent with Hellenistic ideas about kingship. He is presented as temperate and self-controlled, and his experiences as a shepherd and a master of Potiphar's house are also emphasized. ${ }^{29}$ Additionally, there are further parallels with various Neopythagorean texts. ${ }^{30}$

Joseph's role as a dream interpreter is necessarily central to Philo's portrayal of him as a great leader. According to the biblical text, it is Joseph's interpretation of Pharaoh's dreams that leads to his position of leadership

\footnotetext{
28) My interpretation of this passage is further supported by Somn. 2.302. Both passages deny the apparent meaning of the discussion and suggest that it is but a likeness of the

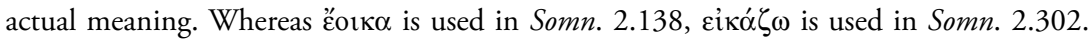
This is Philo's way of reminding his reader that he is speaking allegorically. Also see

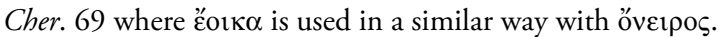

29) E.R. Goodenough (1938) 42-63; J. Laporte (1961) 23-25, 30-1.

30) J. Laporte (1961) 27-30. There are a number of parallels between Philo's description of the ideal ruler and the Neopythagorean treatises by Ecphantus, Diotogenes, and Sthenidas. On these treatises, see L. Delatte (1942).
} 
in Egypt (Gen. 41.38-45). After describing the literal narrative, Philo turns to an allegorical interpretation in which he equates the dream interpreter

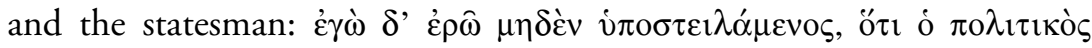

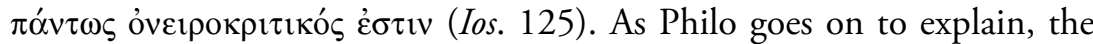
statesman is no ordinary dream interpreter; rather, the dream he interprets

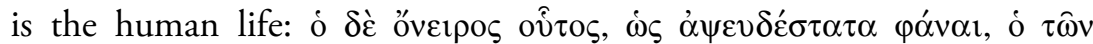

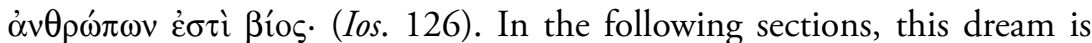
characterized by Philo as the fantasies and false appearances to which most people are subject throughout their lives. Thus the waking perception of most people can be described as a series of dream visions that lack reality. The extended passage (Ios. 125-47) in which Philo describes the dream of life has received attention by scholars because it reveals the influence of Heraclitus in its description of the constant change with which life is characterized and possibly even a Skeptic source. ${ }^{31}$ In the concluding sections, Philo returns to the comparison between the dream interpreter and the politician:

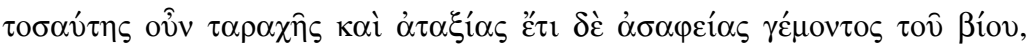

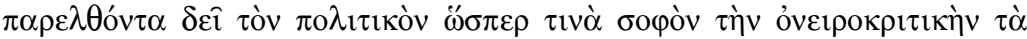

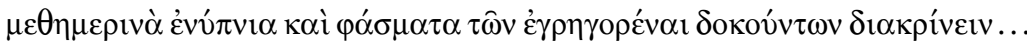
$($ Ios. 143) 32

Therefore, since life is full of such disorder and confusion and even lack of clarity, it is necessary for the politician to come forward and just as the wise dream interpreter to interpret the daytime dreams and phantoms of those who seem to be awake....

The link that Philo draws between the dream interpreter and the politician has no parallel in other sources and for this reason has been criticized by

\footnotetext{
31) See H. Arnim (1888) 53-100 (esp. 94-100). After showing that Philo is the earliest witness to the tropes of Aenesidemus in Ebr. 171-205, Arnim goes on to discuss Heraclitean and Skeptic elements in Ios. 125-47. In particular, he emphasizes the close parallels between Plutarch, De E apud Delpos 18 where Heraclitus is mentioned by name and Ios. 127-129. He concludes that the influence of Heraclitus came to Philo through a Skeptic source. Also see J. Laporte (1961) 33-8 and F.H. Colson (1935) 601-2 for discussions of these issues.

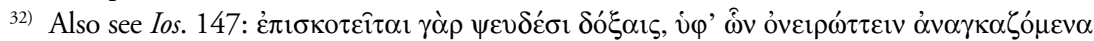

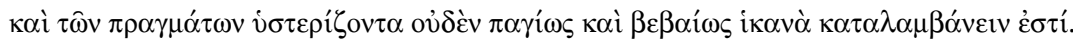


E.R. Goodenough as a 'labored allegory'. ${ }^{33}$ His point is that there is no evidence that the ideal statesman was ever characterized as a dream interpreter, and as a result, Philo only resorts to this interpretation since he is faced with the dilemma of making sense of Joseph's role as a dream interpreter in the biblical text. This view assumes that Philo is attempting to force an allegorical interpretation on the text, which is otherwise inconsistent with his exegetical goals. In contrast, I would like to propose that Philo's figurative use of the dream interpreter is just an extension of his epistemological metaphors relating to dreaming and is directly or indirectly based on Plato's description of the philosopher king. ${ }^{34}$

Although Plato does not refer to the philosopher king as a dream interpreter, he does use the figurative language of sleep and dreaming to characterize the just rule of the ideal leader. Having described the allegory of the cave in book 7 of the Republic, Socrates emphasizes that the one who escapes the shadows of the cave and comes into contact with their source must return to help those still deceived by the shadows. In the same way, after the guardians have received their theoretical education, they are obligated for the good of the community to engage in practical governance. In contrast to these leaders in the ideal state who are awake (ï $\pi \alpha \rho)$, the leaders in other cities lack this theoretical knowledge, and thus their cities are ruled as if in a dream (öv $\alpha \rho) .{ }^{35}$

In two additional passages where Plato describes the true knowledge of philosophers, there are references to the figurative dream of life. In book 5 of the Republic, Plato contrasts the lovers of spectacles with philosophers. The former only delight in particular beautiful things, but the latter look to beauty itself. In this respect, it is asked whether the lovers of spectacles live

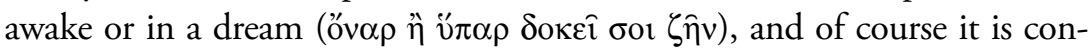
firmed that they dream while awake. Plato further characterizes this as a difference between $\gamma v \omega \dot{\mu \eta}$ and $\delta o ́ \xi \alpha .{ }^{36}$ This idea is similarly expressed in terms of $\delta o^{\prime} \xi \alpha$ and $\dot{\varepsilon} \pi \iota \tau \tau \dot{\mu} \mu \eta$ in book 7 of the Republic. The one who has only $\delta \delta^{\prime} \xi \alpha$

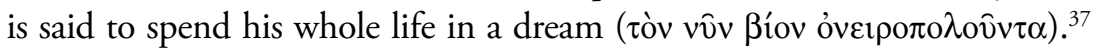

\footnotetext{
33) Goodenough (1938) 56.

34) See M. Alexandre (1999) 188-92 for a description of the rhetorical structure of Ios. 125-47.

35) Resp. 7.520b-c.

36) Resp. 5.476c-d.

37) Resp. 7.534c4-d1. See D. Gallop (1971) 190-92 for further discussion of these passages
} 
Although the wording is different, Plato's references to the dream of life in these passagesare the closest parallel to Philo's description of it in De Iosepho but have not been considered by scholars in relation to it. ${ }^{38}$

Philo's emphasis on Joseph as a politician and a dream interpreter begins to make much more sense when viewed against the backdrop of Plato's figurative language of sleep and dreaming in relation to his theory of knowledge and the philosopher kings. Considering that the biblical text provides a literal account of Joseph becoming a ruler as a result of his ability to interpret dreams, it was not a great leap for Philo to emphasize Joseph's role as a dream interpreter. ${ }^{39} \mathrm{He}$ (or his source) simply expanded the philosophical metaphors to account for the specifics of the biblical narrative. In any case, it certainly seems to be the product of an exegete in the Platonic tradition trying to make sense of the biblical story of Joseph. Considered in this light, Philo's discussion of Joseph as a dream interpreter was not really out of place in a treatise presenting him as an ideal ruler.

\section{Joseph's Transformation from Dreamer to Dream Interpreter}

From the discussion thus far, it is evident that Philo has two distinct ways of allegorizing Joseph: the dreamer in a deep sleep who lacks knowledge

in the context of Plato's figurative use of dreams and his theory of knowledge. Gallop describes three characteristics that are commonly associated with dreams: lack of clarity, incoherence, and lack of stability. He then shows that these are the same characteristics Plato uses to describe the inferior knowledge of the sensible world in contrast to the superior world of intelligibles. Similarly, I would like to point out that Philo also applies these characteristics to knowledge when he is using sleep and dreams as epistemological metaphors. See esp. Somn. 2.105-8, 138, 162; and Ios. 147.

38) Cf. Plato, Meno 99c-d where the distinction between $\delta o ́ \xi \alpha$ and $\dot{\varepsilon} \pi \_\tau \hat{\eta} \mu \eta$ is related to politics; and Resp. 3.414d where the education of the guardians is described as a dream. According to D. Gallop (1971) 192, this is meant to emphasize that their early education '.. exposed them to sensible images of Beauty and other Forms, which they would see directly only later in life when trained in dialectic.'

39) M. Petit (1987) argues that the link between dream interpreter and statesman is literal whereas the notion that the most people are subject to delusion regarding the world of appearances is allegorical. Petit also points out that Pharaoh's dream had significance for the whole country whereas the dreams of the other Egyptians only have significance for the individual dreamers. In this way, interpretation of a dream with impact for the whole nation justifies Joseph becoming a leader of that nation. 
and the dream interpreter who possesses knowledge and thus dispels the dream of life for others. The question remains, however, whether these are just two conflicting ways Philo interpreted Joseph at different times or are they a part of a coherent exegetical strategy.

First of all, it is evident that Philo thought that Joseph underwent some kind of epistemological and ethical transformation in his life. In De somniis 2, Philo explains that Joseph will one day wake up from his figurative deep sleep and stop dreaming. Discussing the hate the brothers have for Joseph, Philo says that one day this hate will end when Joseph has changed for the better:

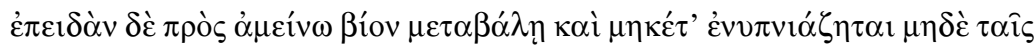

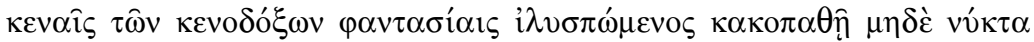

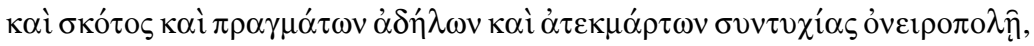

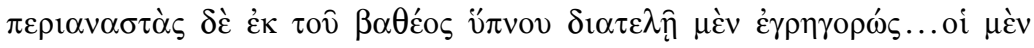

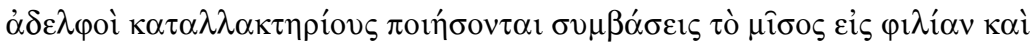

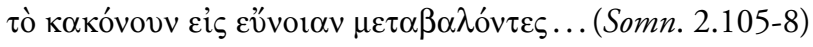

And whenever he (i.e. Joseph) changes his life for the better and no longer dreams nor suffers the vain fantasies of vainglory as he crawls along nor dreams of night and darkness and the events of unclear and unproven deeds, but after waking up from a deep slumber, continues in his wakefulness... then the brothers will make reconciliatory agreements as they change their hate to love and their ill-will to goodwill...

It is unclear if Philo understands this change within a literal chronology, but it is at least evident that Philo in some sense perceived an end to the figurative delusions of Joseph the dreamer. At a later time, his brothers will cease their hate when he wakes up, as it were, from this deep sleep ( $\dot{\varepsilon} \kappa \tau$

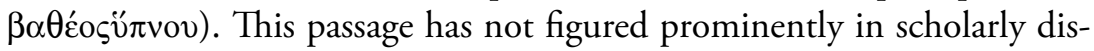
cussions regarding Philo's seemingly contradictory presentations of Joseph, but if taken seriously, it has important consequences for the debate: Joseph can be presented in two different ways because he went through an major transformation which sharply distinguishes the two periods of his life.

One might argue that Joseph's figurative waking up does not adequately account for his ability to be a leader who can interpret the figurative dream of life, as in De Iosepho. After all, just because one comes to a deeper state of knowledge does not mean that one is able to dispel the ignorance of others. My point throughout this article is to show that Philo's seemingly contradictory presentations of Joseph are a part of a coherent scheme when 
examined in terms of the language of sleep and dreaming. For this reason, it would be helpful to find passages that suggest that Joseph's transformation made him a virtuous leader. In what follows, I will show that a strong case can be made for this when one examines Philo's use of the language of sleep/dreaming in relation to his use of the language of mystery religion.

It is generally agreed that there is no evidence that Philo's numerous references to the mysteries indicate the existence of Jewish rites similar to those practiced in pagan mystery cults. Instead, the mystery of which Philo speaks is the mystery of true philosophy (i.e. mystic Judaism). In this sense, Philo is similar to other Greek philosophers who consider the true mysteries a transformation without rites, which results in purification and divine knowledge. ${ }^{40}$ Although this intangible mystery was certainly a reality for Philo, his expressions are metaphorical to the extent that they do not refer to a specific ritual practice. Instead, his expressions are stylistic devices inherited from Plato, which he often uses to refer to a deeper understanding of Scripture. ${ }^{41}$ Thus Philo's use of mystery terminology has strong epistemological associations and can be used to describe a transformation of knowledge. It is in this way that it is similar to his use of the figurative language of sleep and dreaming.

Due to the epistemological associations of both sets of figurative language, Philo can combine them. An example of this is when he is discussing Jacob's dream of the ladder in De somniis 1 . Philo explains that certain passages have the ability to enlighten those who are intellectually blind so that they do not rely exclusively on a literal reading of the text. However, even if one closes his mind's eye, Moses, the high-priest, has the ability to open one's eyes and reveal that which was previously hidden:

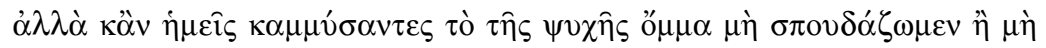

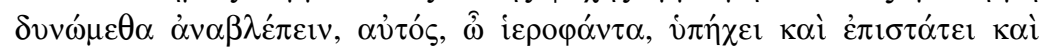

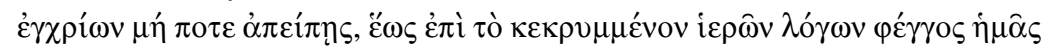

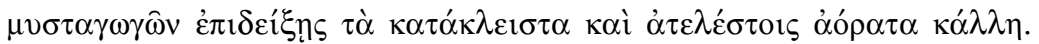

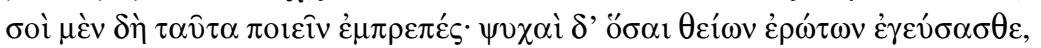

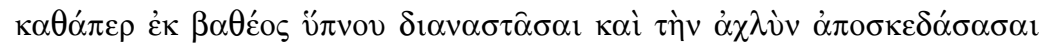

\footnotetext{
40) E.R. Goodenough (1937) 227-241.

41) C. Riedweg (1987) 70-115. Unfortunately, Riedweg does not address the connection between mystery terminology and sleep/dreaming. Also see M. Petit (1974) 153-4. Petit briefly mentions that Philo employs the vocabulary of mystery religion in order to describe Joseph as a dreamer but does not elaborate.
} 


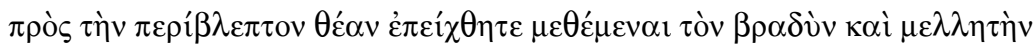

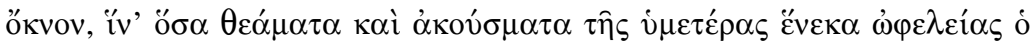

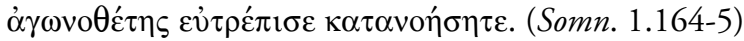

But even if we do not hasten to look up or are not able to after we have shut our mind's eye, you, Sacred Guide (i.e. Moses), you speak to us internally and take charge and never cease from anointing, until you initiate us into the hidden light and show those beautiful things which are locked up and invisible to those uninitiated. Indeed, it is fitting for you to do these things; and you souls, as many of you who have tasted divine loves, after getting up as if from a deep sleep and wiping the mist from your eyes, hasten to the sight which is admired by all as you get rid of that slow and obstructing burden, in order that you may understand as many sights and sounds as the judge has prepared for your benefit.

Words such as $\mu v \sigma \tau \alpha \gamma \omega \gamma \hat{\omega} v$ and $\dot{\alpha} \tau \varepsilon \dot{\lambda} \varepsilon \sigma \tau$ or are blatant appropriations of mystery terminology, and the imagery of light and vision also has these associations. ${ }^{42}$ Moses, in his role as the inspired author of the Pentateuch, is the mystagogue who is able to lead one into mystic initiation (i.e. a deeper understanding of Scripture). Most importantly for my purposes, this mystic transformation is described as a waking up from a deep sleep

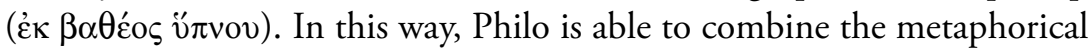
language of sleep and mystery cults because both are ways that he refers to

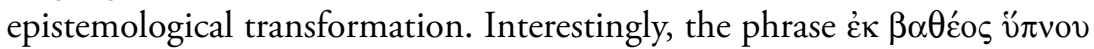
is also used in the passage cited above about Joseph's transformation. ${ }^{43}$

Moses' role as an initiator of mystic rites is further explained in De gigantibus where Philo describes Moses' own figurative initiation. Referring to a passage where Moses is said to have pitched his tent outside of the camp (Ex. 33.7), Philo explains that it was there that Moses learned the secrets of the holy mysteries. ${ }^{44}$ In doing this, Moses became not only an initiate ( $\mu$ v́ $\tau \eta \varsigma)$ with knowledge of the mysteries but also one capable of imparting this knowledge to others. In this role, he is specifically called a

\footnotetext{
42) See Riedweg (1987) 96-8 on the mystery terminology found in this passage. Riedweg does not mention the figurative use of sleep. Also see Goodenough (1935) 233.

43) Philo always uses this phrase figuratively. Often, it has an epistemological connotation and/or refers to some kind of transformation. In addition to the passages cited above, also see Cher. 62; Deus. 39, 97; Abr. 70; Somn. 2.18. Cf. Wisdom of Ben Sira 22.9 and Clement of Alexandria, Paedagogus 1.8.66.3.

44) Gig. 54. See Riedweg (1987) 104-5 on the mystery terminology found in this passage.
} 


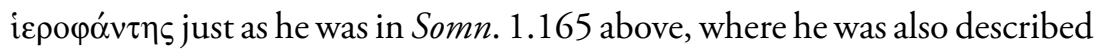
as a $\mu v \sigma \tau \alpha \gamma \omega \gamma o ́$ s. Philo's depiction of Moses as one who underwent an initiation and was thus able to initiate others provides an important parallel for Philo's presentation of Joseph.

When Philo is discussing the way Joseph described his second dream in De somniis 2, Joseph is said to be both an initiate and an initiator of dreams:

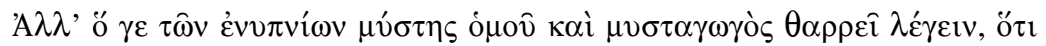

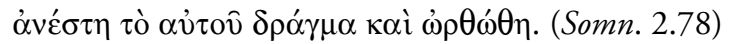

But the one who was at the same time an initiate and an initiator of dreams boldly says that his sheaf got up and stood straight.

The language of mystery religion is here used to describe Joseph's roles as a dreamer and a dream interpreter. In other words, Philo conceives of dream interpretation as a kind of mystic initiation. The dreamer is the one who has the dream, but the dream interpreter brings the dreamer to understanding by interpreting his dream. As I have explained, the reason Philo can use the language of mystery religion in this context is that dreaming also has an important epistemological connotation for Philo. If this passage is read against the background of the other passages relating to Moses that I described above, then it is very revealing with respect to Philo's presentation of Joseph in De Iosepho. Joseph's ability as a leader to interpret the dream of life is no different from Moses' ability to act as a mystagogue who can lead one into a deeper understanding of Scripture. Figuratively speaking, it is the product of a mystic transformation, which results not only in initiation but also in the ability to lead others to a deeper state of knowledge. When Philo refers to Joseph as both an initiate and an initiator of dreams, he is admitting that Joseph embodies both of these roles since he went through an epistemological transformation. In other words, Joseph's negative and positive associations are a part of a coherent exegetical strategy in which he is at one time only an initiate and at another time the initiator.

\section{Conclusion}

The purpose of this article has been to show the importance of the figurative language of sleep and dreaming for Philo's treatment of Joseph. As a dreamer and a dream interpreter, Joseph embodies both the negative qualities of a dreamer who is subject to delusion and the positive qualities 
of the dream interpreter who is able, as it were, to dispel the delusion of dreaming. While De somniis 2 and De Iosepho may each emphasize only one of these to the exclusion of the other, there is no reason to see these presentations as contradictions of substance. As I have shown, Joseph is understood as having undergone a transformation from ignorance to knowledge, which Philo expresses in terms of a figurative waking up.

I should also stress that my approach does not necessarily conflict with that ofscholars who have explained the differences between De somniis 2 and De Iosepho in terms of Philo's audience or contemporary political motivations. There is no reason why Philo's shift in exegetical foci might not reflect contemporary historical issues or the audiences to whom the texts are directed. My emphasis on his use of the figurative language has simply shown that Philo's notion of consistency is often guided to a large extent by philosophical metaphor and its relation to the content of Scripture.

\section{Bibliography}

Alexandre, M. 1999. Rhetorical Argumentation in Philo of Alexandria. Atlanta, GA: Scholars Press.

Arnim, H. von. 1888. Quellenstudien zu Philo von Alexandria. Berlin: Weidmann.

Bassler, J.M. 1985. 'Philo on Joseph: the basic coherence of De Iosepho and De Somniis II'. JSJ 16, 240-255.

Billings, T.H. 1919. The Platonism of Philo Judaeus. Chicago: University of Chicago Press.

Brown, C. 1986. 'Seeing Sleep: Heraclitus Fr. 49 Marcovich (DK 22 B 21)'. AJP 107, 243-245.

Colson, F.H. 1935. Philo with an English Translation. Loeb vol. 6. Cambridge, MA: Harvard University Press.

Delatte, L. 1942. Les Traités de la Royauté d'Ecphante, Diotogène et Sthénidas. Pari: Belles Lettres.

Diels, Hermann and Walter Kranz. 1951-2. Die Fragmente der Vorsokratiker, 6th ed. 3 vol. Berlin: Weidmann.

Frazier, F. 2002. 'Les Visages de Joseph dans le De Josepho'. The StudiaPhilonica Annual 14, 1-30.

Gallop, D. 1971. 'Dreaming and Waking in Plato', in J.P. Anton and G.L. Kustas (eds.), Essays in Ancient Greek Philosophy, vol. 1, Albany: State University of New York Press, 187-201.

Goodenough, E.R. 1935. By Light, Light: The Mystical Gospel of Hellenistic Judaism. New Haven: Yale University Press.

—. 1937. 'Literal Mystery in Hellenistic Judaism', in Robert P. Casey et al. (eds.), Quantulacumque: Studies Presented to Kirsopp Lake by Pupils, Colleagues and Friends, London: Christophers, 227-241. 
1938. The Politics of Philo Judaeus. New Haven: Yale University Press.

Graffigna, P. 1988. 'Il molteplice e l'eccedente: tuphos in Filone d'Alessandria'. Quaderni di Semantica IX 2, 347-55.

Granger, H. 2000. 'Death's Other Kingdom: Heraclitus on the Life of the Foolish and the Wise'. CP 95, 260-81.

Harris, W.V. 2009. Dreams and Experience in Classical Antiquity. Cambridge, MA: Harvard University Press.

Havelock, E.A. 1963. Preface to Plato. Oxford: Basil Blackwell.

Hilgert, E. 1986. 'A Survey of Previous Scholarship on Philo's De Josepho'. SBLSP 25, 262-270.

Hilgert, E. 1987. 'A Survey of Previous Scholarship on Philo's De Somniis 1-2'. SBLSP 26, 394-402.

Kessels, A.H.M. 1978. Studies on the Dream in Greek Literature. Utrecht: HES.

Laberge, L. 1978. La Septante d'Isä̈e 28-33. Étude de tradition textuelle. Ottawa: Laberge.

Laporte, J. 1964. De Iosepho. vol. 21 Les oeuvres de Philon d'Alexandrie, French translation under the general editorship of Roger Arnaldez, Jean Pouilloux, and Claude Mondésert Paris: Cerf, 1961-92.

Lieshout, R.G.A. 1980. Greeks on Dreams. Utrecht: HES.

Louis, P. 1945. Les métaphores de Platon. Paris: Belles Lettres.

Mansfeld, J. 1967. 'Heraclitus on the Psychology and Physiology of Sleep and on Rivers'. Mnemosyne 20, 1-29.

Mikeš, V. 2007. 'Obraz snu a spánku u Hérakleita a Platóna a jeho filosofické Souvislosti' ('The Metaphor of Sleep and Dream in Heraclitus and Plato and Its Philosophical Context'). Listy Filologické 130, 229-49.

Näf, B. 2004. Traum und Traumdeutung im Altertum, Darmstadt: Wissenschaftleche Buchgesellschaft.

Nikiprowetzky, V. 1977. Le commentaire de l'écriture chez Philon d'Alexandrie: son caractère et sa portée, observations philologiques. Leiden: Brill.

Obbink, D. 1996. Philodemus:On Piety.Oxford: Oxford University Press.

Petit, M. 1974. 'Les songes dans l'oeuvre de Philon d'Alexandrie', in Mélange d'histoire des religions offerts à H.C. Puech. Paris: Presses Universitaires de France, 151-159.

—. 1987. 'L'homme politique: interprète de rêves selon Philon d'Alexandrie (De Iosepho 125)', in D. Tolles (ed.), Politique et religion dans le judaïsme. Interventions au Colloque des 8 et 9 décembre 1987 organisé par le Centre d'Études Juives de l'Université Paris-IV Sorbonne, Paris: Université de Paris-Sorbonne, 41-53.

Polito, R. 2003. 'Sextus on Heraclitus on Sleep', in T.Widemann and K. Dowden (eds.), Sleep, Nottingham Classical Literature Studies, vol. 8, Bari: Levante, 53-70.

Rankin, H.D. 1964. 'Dream/Vision as Philosophical Modifier in Plato's Republic'. Eranos 62, 75-83.

Riedweg, C. 1987. Mysterienterminologie bei Platon, Philon und Klemens von Alexandrien. Berlin: de Gruyter.

Sandmel, S. 1979. Philo of Alexandria: An Introduction. New York: Oxford University Press.

Tigner, S.S. 1970. 'Plato's Philosophical use of the Dream Metaphor'. AJP 91, 204-212. 
Torallas, Tovar, S. 1995. El De Somniis de Filón de Alejandría. Universidad Complutense de Madrid Ph.D.

—. 2003. 'Philo of Alexandria on Sleep', in T. Widemann and K. Dowden (eds.), Sleep. Nottingham Classical Literature Studies, vol. 8, Bari: Levante, 41-52.

Winston, D. 1984. 'Philo's Ethical Theory', ANRW 21.1, 372-416.

Zeitlin, S. 1975-1976. 'Dreams and Their Interpretation from the Biblical Period to the Tannaitic Time: An Historical Study'. JQR 66, 1-18. 